JASEM ISSN 1119-8362

All rights reserved
Full-text Available Online at www.bioline.org.br/ja
J. Appl. Sci. Environ. Mgt. September, 2006

Vol. 10 (3) 31 - 35

\title{
Lignite Zone as an Indicator to Lost Circulation Belt: A Case Study of Some Locations of Anambra State, Southeastern Nigeria.
}

\author{
NFOR, B N \\ Department of Geology, Delta State University, P.M.B. 01 Abraka, Delta State, Nigeria.
}

\begin{abstract}
Eighteen (18) water boreholes were studied for lost circulation. When locations of the boreholes associated with lost circulation were plotted on the map of Anambra State a lost circulation belt was observed around the River Niger - Onitsha - Oba - Nnewi axis. Lost circulation intervals range between 20-50m and 75-90m depth and were found to be associated with lignite and peaty clay members of the Ogwashi-Asaba Formation and/or the Ameki/Bende Formation. This suggests that natural rather than anthropogenic factors are responsible for the widespread occurrence of lost circulation in the State, although the latter could aggravate the former. Lignite and peaty clay of the Ogwashi-Asaba and Ameki/Bende Formation cause lost circulation because they are woody to earthy in nature and are easily eroded when they occur above the water table. These conditions favour the development of vugs, leading to increase in permeability and porosity, making the formation prone to lost circulation. Pre-drilling geophysical, geological and hydrogeological investigations are recommended, since these would go a long way to identify the presence or absence of lignite and thus help to avert possible lost circulation intervals. @j j JASEM
\end{abstract}

The study of the occurrence of lost circulation associated with lignites was carried out for some localities of Anambra State, southeastern Nigeria (fig. 1). The State lies within longitudes $6^{0} 37^{\prime} \mathrm{E}$ and $7^{0} 20^{\prime} \mathrm{E}$ and latitudes $5^{\circ} 40^{\prime} \mathrm{N}$ and $6^{\circ} 49^{\prime} \mathrm{N}$. Several cases of widespread lost circulation had been reported from boreholes under construction in Anambra State. The focus of the present study is to map loss circulation intervals; the towns/villages prone to loss circulation, establish the cause(s) of lost circulation and examine the correlation between lost circulation and the occurrence of lignite. Lost circulation is loss of substantial quantities of drilling mud to an encountered formation during borehole drilling. This is evidenced by a total or drastic reduction of returning mud and a reduction in the volume of mud in the mud pits. The following could cause lost circulation: borehole pressure (mud pressure) being in excess of the formation pressure; damaged formations due to reckless drilling; pipe surging at high speeds; fractured, fissured or faulted formations; limestone regions, which are vuggy and very coarse; permeable rocks like pebbles, reefs and irregular limestone, gravels and conglomerates. The undesirable effects of lost circulation include; Loss of drilling energy, sudden undesirable speed increase of the rotary, deflection of the bit along joint planes or even breaking of the bit, drilling fluid may be totally lost, hence increased cost of operation, time wasted in pulling back and/or combating lost circulation, drop in annular level may cause blow out in over-pressured or gas-bearing formations, loss of information from the down-hole, the chances of stuck-pipe and fishing exercise are increased, if lost circulation occurs in an aquiferous zone, or slightly above it, then completion and development of the borehole may be impaired.

Geologic Units within the Anambra Basin.: The Basin is dominantly filled with clastic sediments constituting several distinct lithostratigraphic units ranging from Upper Campanian to Recent in age. The lithostratigraphic units have a thickness of up to $2500 \mathrm{~m}$ (Reyment, 1965) and consist of; Npkoro Shale, Mamu Formation, Ajali Sandstone, Nsukka Formation, Imo Shale, Ameki Formation, Nanka Sands, Ogwashi-Asaba Formation, Benin Formation and the Alluvial plain Sands. The source of the sediments into the basin is principally from the Cameroon massif and the Abakaliki synclinorium, (Nfor, 2003).

Methodology: Progress reports on boreholes under construction were collected. A plot of boreholes associated with lost circulation was made on the map of Anambra State and used to identify towns and intervals prone to lost circulation. This was then used to predict (by interpolation) towns/villages prone to lost circulation. Furthermore, the intervals of lost circulation were compared with the lithologies and the relationship between the two investigated.

*Correspondence: E - mail: nforbng@yahoo.com. Tel+234-8055429516 


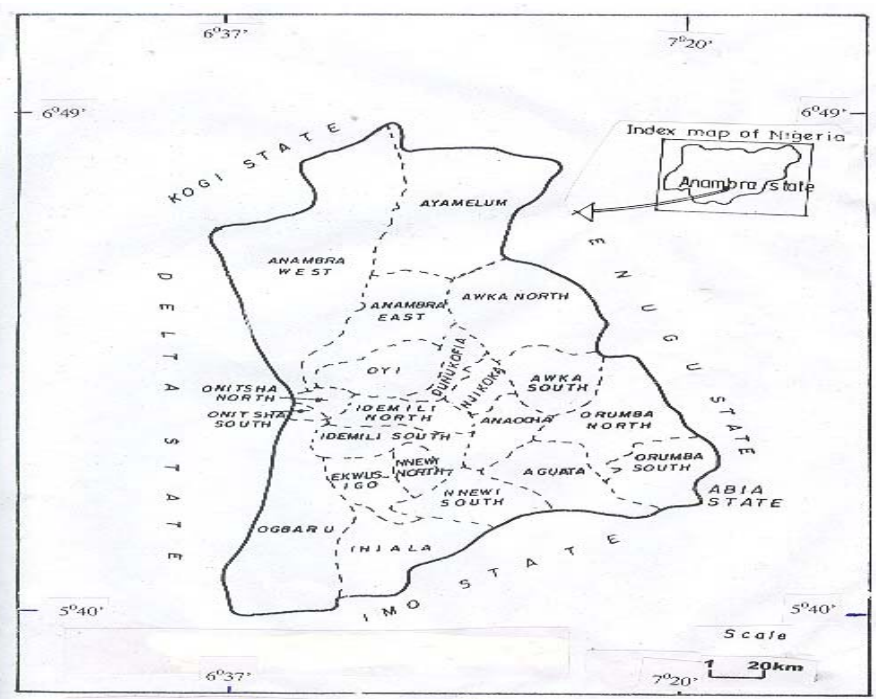

Fig. 1: Map of Anambra State showing its Local Government Areas. Inset is map of Nigeria

Data Presentation, Analysis and Discussions. The boreholes studied are presented in figure 2. The borehole in which lost circulation was encountered and the interval(s) of occurrence are marked as (*). A record of the boreholes associated with lost circulation and the intervals of occurrence are tabulated and presented in Table 1.

The analyzed data indicate that lost circulation is confined to six (6) Local Government Areas
(L.G.As) of Anambra State, namely; Ekwusigo, Idemili North, Idemili South, Nnewi North, Nnewi South and Ihiala as shown in figure 3 and Table 1.

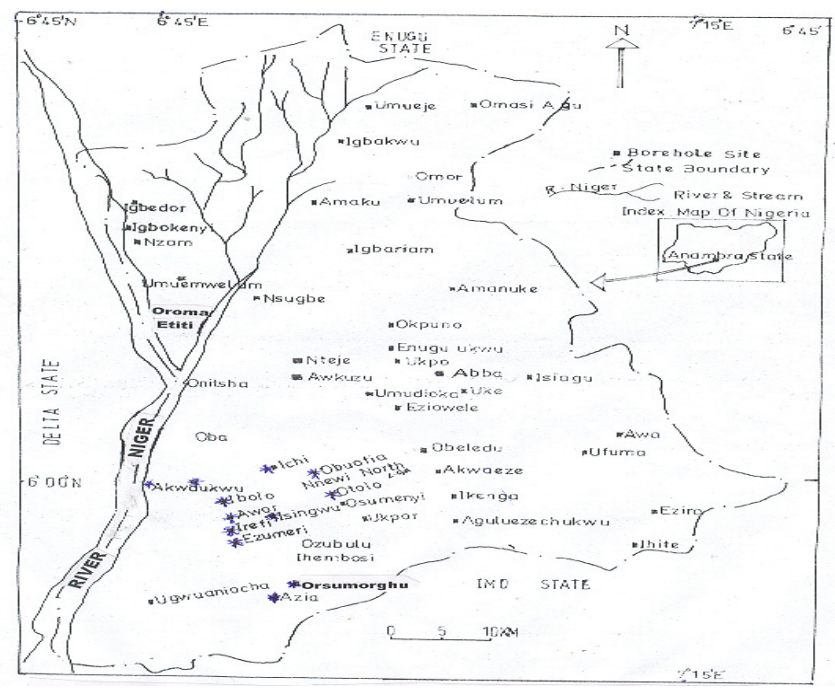

Fig. 2: Positions of boreholes. Boreholes with asterisks are associated with lost circulation 
Table 1: Sites of Lost Circulation in Anambra State.

\begin{tabular}{lll}
\hline Site & Local Government Area & Interval(s) in meters \\
\hline Ibolo-Oraifite & & $70-100$ \\
Awor-Ifite & & $85-150$ \\
Irefi I ${ }^{*}$ & & $80-130$ \\
Irefi II & & $85-130$ \\
Ezumeri & EKWUSIGO & $75-125$ \\
Isingwu & & $75-125$ \\
Nnewi-Ichi I* & & $25-34$ \\
Nnewi-Ichi II & & $25-34 ; 90-100$ \\
Akwaukwu I & & $44-70$ \\
Akwaukwu II & IDEMILI SOUTH & $44-50$ \\
Akwaukwu III & & $34-36$ \\
Uke & IDEMILI NORTH & $60-80 ; 140-145 ; 170-187$ \\
Obiofia & & $32-42$ \\
Otolo - Nnewi I & NNEWI NORTH & $34-36$ \\
Otolo-Nnewi II & & $34-40 ; 120-124$ \\
Osumenyi & NNEWI SOUTH & $20-25$ \\
Osumorghu & IHIALA & $66-65 ; 90-100$ \\
Azia & & $50-60 ; 90-100$ \\
\hline
\end{tabular}

* Failed and abandoned boreholes. Data compiled by Nfor, B.N. (2001)

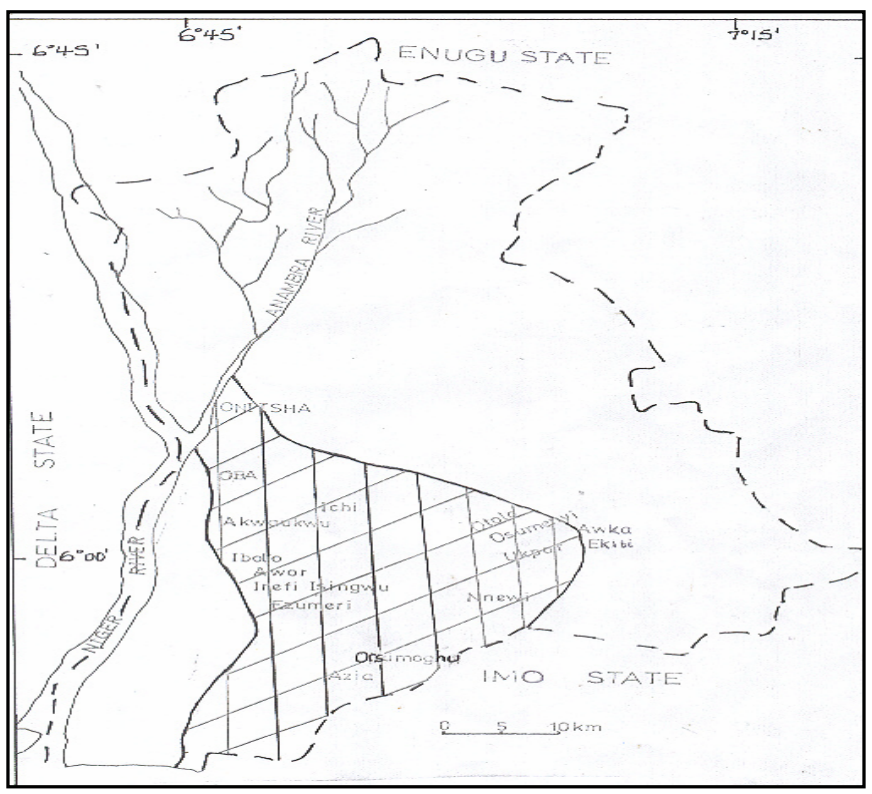

Fig. 3: Lost Circulation zone of Anambra State.

This L.G.As are located between the west and southwestern part of Anambra, with the greatest intensities of lost circulation occurring around Akwaukwu, Oraifite, Nnewi and the River Niger areas. Such a concentration towards R. Niger, and its tributaries prompted more investigations on boreholes in Onitsha and Ogbaru L.G.As and the Oba areas. No reports of lost circulation have however been made from these locations except in areas around Oba, a town located some $10 \mathrm{~km}$ south of Onitsha and $4 \mathrm{~km}$ north of Akwaukwu. The extent of damage caused by lost circulation in terms of money and time spent in combating it is reflected in the extra number of boreholes drilled after an initial borehole had failed and abandoned. In Akwaukwu, all the three boreholes drilled were abandoned and 
the cost incurred in terms of anti-loss circulation materials, chemicals and overhead was about four million naira ( $\$$ m) as at 1998 . In Nnewi-Ichi and Otolo-Nnewi, an extra sum of 4.5 million naira ( $\$ 4.5 \mathrm{~m}$ ) and two extra months were spent to combat lost circulation to success. In Irefi, one million naira (N1m) was expended in the combat (personal computation). It was observed that severe lost circulation intervals mostly lie between $25-50 \mathrm{~m}$ and $75-90 \mathrm{~m}$, whereas the water table lies far below (about $150 \mathrm{~m}$ ). The consistency in the depth of occurrence and the wide aerial extent of loss circulation suggests that natural factors rather that anthropogenic are responsible, although the latter could aggravate them. Consequently, the lithologies (a natural factor) encountered at lost circulation intervals were investigated. Fig. 4 shows the lithologic logs of the boreholes. When lignite occurs above the water table, it is commonly oxidized and eroded. Furthermore some intraformational unconformities, including cobbles and gravels encountered during drilling as well as and vugs in the lignites provide pathways and channels for whole or partial mud loss. Shales could be highly fractured and fissured and if they underlie lignites at high dip angles, they could convey any water (due to their impermeability) unto spring points. The widespread occurrence of lignites in that belt is associated with the country in which it occurs; generally undulating, deeply incised and is of low to moderate altitude, ranging from less than $30 \mathrm{~m}$ in the near R. Niger, around Onitsha to about $150 \mathrm{~m}$ near Osumoghu in Ihiala L.G.A. and could even occur beyond to Imo State and Cross River (Offodile). The main drainage systems of the area traverse it in a general northsouth direction, as do R. Niger, Orashi, Ekulu River, Ogba etc. The combined effect of the drainage system and subdued topography could have favoured the growth of coal-forming forests probably dominated by palms. Since these materials, which grew on a shale substrate, have not decomposed beyond the peat and lignite stages of coal, vugs are still abundant. These woody-to-earthy; and vuggy materials when encountered during drilling provide pathways for loss of drilling mud. Palynological study of some lignites from outcrops around Toll gate, at Ogbunike some $5 \mathrm{~km}$ from Onitsha, along the Onitsha expressway, shows that the pollen grains were derived from the tropical and semi-tropical plants, mostly palms. These palms produce high wax and resin contents (Nfor, 2003). Previous workers; Geological Survey of Nigeria, (1985); Jean Du Chene, Onyike and Sowsun); Reyment, (1965) have shown that the lignites of the Onitsha-Oba-Nnewi axis occur in the Lignite Group of Miocene to Oligocene in age and the Ogwashi-Asaba Formation was proposed by Reyment,

(1965)

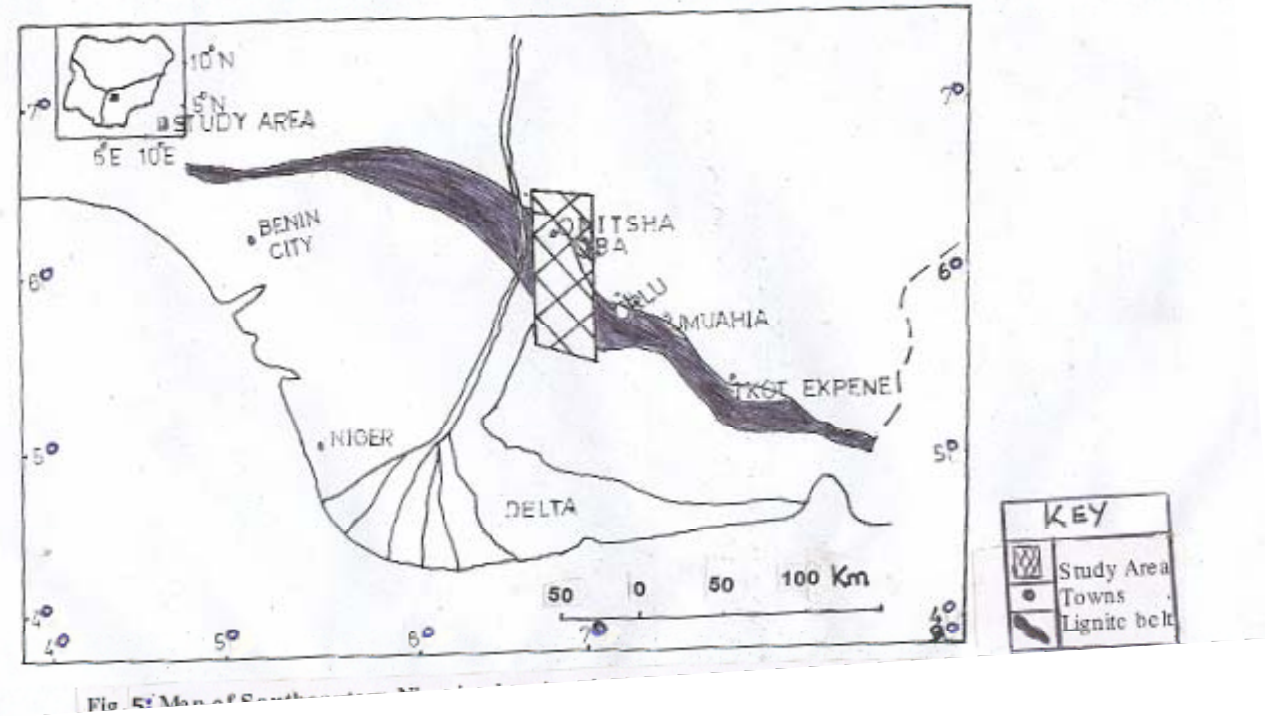

Fig. 5: Map of Southeastern Nigeria showing the location of Onitsha and lignite seam zone. Inset is map of Nigeria. (After Okeke and Ezem, 1993) 
Du Preeze (1945), provisionally recognized Upper and Lower horizons in the Nnewi-Oba part of the field where the lignite seams are interbedded with lenses of unconsolidated sands and clays. Considering that Du Preeze (1945), studied mainly outcrops at river-cuts, his upper and lower lignites horizons could correspond to the $20-25 \mathrm{~m}$ depth lignite intervals encountered in the present study, which interfinger/intertongue or thin-out sand and shale beds. This implies that the lignites at depths of $34-50 \mathrm{~m}$, the lower lignites at depths of $170-178 \mathrm{~m}$ or even beyond could appropriately be named Deep lignite horizons. Seismic surveys by Okeke and Ezem (1993) show that the lignite seams in the Onitsha-Oba-Nnewi axis is at least $16 \mathrm{~m}$ of depth. From their studies, Okeke and Ezem (1993), demarcated the lignite seam zone, (fig. 5). A comparison between figures 3,4 and 5 shows that the lost circulation belt behaves sympathetically with the lignite zone. According to borehole reports published by the Geological Survey of Nigeria Occasional Paper (1985), lignite was encountered at depths 49-52m; 18-21; 50-52m in Nnewi, Nnewi suburbs and Ozubulu boreholes respectively. The same report recorded lignite seams exposed at the following places; Ukpor, Uruagu, Ihiala, Ogba River, Oba etc.

Combating Lost Circulation. There is need for drillers to watch out for lost circulation not only in the afore-mentioned towns and villages but anywhere worldwide where lignites overlay aquifers. The application of anti-lost circulation materials like foam, coconut shells, mica, saw dust, cassava pilings and even laterite, drilling through a conductor pipe. This can also be cheaply achieved by using percussion or cable tool rigs. The use of the latter method, however, is restricted by great depth and sloughing shales. Air drilling is also very valuable in these areas and compressor-mounted rigs are thus recommended for combating lost circulation. Modification of mud chemistry by increasing the volume of bentonite, and increasing circulation time prior to increasing drill pipe length could also combat lost circulation. Again drilling rate should proceed very slowly and at low mud pressures. Spotting, (the pumping of chemicals down the drill pipe with a sufficient volume of displacing fluid behind it to position plugs at the desired level of lost circulation in the hole) is also a valuable means of combating lost circulation. Experience has shown that it is safer to plan for a dual casing program if lost circulation is suspected. This involves the use of casing of two diameters; $12^{1 / 4}$ - inches and 7-inches.

Conclusion. Lost circulation could be very expensive to remedy if it is drastic as recorded in some parts of the Anambra Basin. It has been shown from available data that a loss circulation belt exists within Anambra State and could even extend to Imo and beyond. The lost circulation belt has been found to occur in lignites, peaty and carbonaceous shales and behaves sympathetically with it. Drilling in such zones require adequate geological, geophysical, technological knowledge and its application to avert abandoning the borehole mid-way down. Drillers are thus advised to embark on thorough pre-drilling surveys and investigations, as these would help them prepare appropriate quotations and litigation clauses as well as get a state-of-the-art technological expertise and enough money before they attempt to drill in this lost circulation belt.

\section{REFERENCES}

Geological Survey of Nigeria Occasional Paper, (1985). Nehikhere, J. I. (Ed.)

Jean DU Chene, R.E.; Onyike, M.S.; Sowunmi, M.A., (1978). Some New Eocene Pollens on the Ogwashi-Asaba Formation, S.E. Nigeria: Revista Espagnol de Micropaleontologia Vol. X (2). Pp 285-321.

Nfor, B.N., (2003). Sedimentary Facies and the Diagnostic Characteristics of the CampanianEocene, Anambra Basin, S.E. Nigeria: PhD Thesis, Department of Geology, Nnamdi Azikiwe University, Awka.

Offodile, M.E., (1991). An Approach to Groundwater Study and Development in Nigeria. Mecon Services Ltd., Jos, Nigeria.P129.

Okeke, P.O.; Ezem, L.N., (1988). Determining Weathered Layer Velocities and Depths to the Lignite Seams of the Anambra Basin, Nigeria by Uphole Seismic Reflection Method. In Groundwater and Mineral Resources on Nigeria. Ofoegbu C.O. (Ed.). Pp. 120 - 139. 